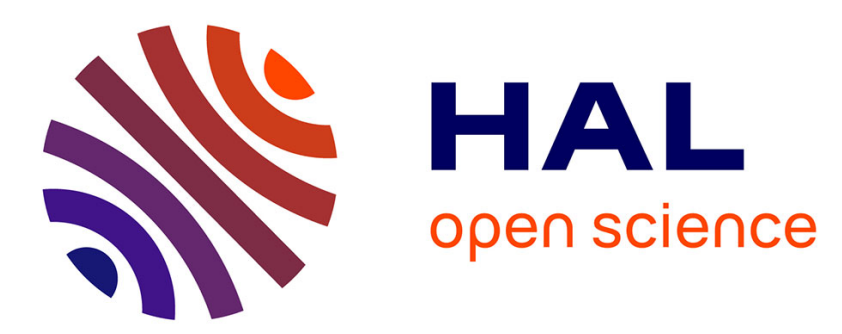

\title{
Elaborating the characteristics-based approach to service innovation: making the service process visible Faïz Gallouj, Marja Toivonen
}

\section{To cite this version:}

Faïz Gallouj, Marja Toivonen. Elaborating the characteristics-based approach to service innovation: making the service process visible. Journal of innovation economics, 2011, 8 (2), pp.33-58. 10.3917/jie.008.0033 . halshs-01133797

\section{HAL Id: halshs-01133797 https://shs.hal.science/halshs-01133797}

Submitted on 20 Mar 2015

HAL is a multi-disciplinary open access archive for the deposit and dissemination of scientific research documents, whether they are published or not. The documents may come from teaching and research institutions in France or abroad, or from public or private research centers.
L'archive ouverte pluridisciplinaire HAL, est destinée au dépôt et à la diffusion de documents scientifiques de niveau recherche, publiés ou non, émanant des établissements d'enseignement et de recherche français ou étrangers, des laboratoires publics ou privés. 


\title{
Elaborating the characteristics-based approach to service innovation: making the service process visible
}

\author{
Faïz Gallouj* and Marja Toivonen** \\ * Clersé, Université Lille1 \\ ** VTT Technical Research Centre of Finland
}

\begin{abstract}
(Published in Journal of Innovation Economics: GALLOUJ F. TOIVONEN M. (2011), Elaborating the characteristics-based approach to service innovation: making the service process visible, Journal of Innovation Economics, 2011/2, n ${ }^{\circ}$, p. 33-58.)
\end{abstract}

\begin{abstract}
This paper tackles the issue of how to make the process nature of services more visible in the characteristics-based service innovation model developed by Gallouj and Weinstein (1997). We argue that the invisibility of the service process in the original model is likely to reduce the use of the model for detailed-level analyses within individual services. In our supplemented model four new aspects are added: a separate category for the process characteristics, the 'front office - back office' division, the customer's technology and process, and the distinction between direct and indirect utilities. We apply our model in two empirical cases, which depict KIBS and consumer services.
\end{abstract}

Keywords: innovation, services, characteristics-based approach

\section{Introduction}

Studies on services are today accumulating rapidly, their focus varying from the issues of the service economy to the features of service sectors and service firms, and further to the nature of service products. An important topic which has aroused growing interest during the last decade is innovation in services. Here, we can identify three basic approaches (Gallouj, 1998, 2002; Gallouj and Savona, 2009). The earliest studies adopted a technologist or assimilation approach, which reduces innovation in services to the introduction of technical systems and focuses on technological cycles and technological trajectories (Barras, 1986; Soete and Miozzo, 1990). As a reaction to this technology- and manufacturing-biased a view, there emerged a service-oriented or differentiation approach, which highlights that innovation in services often follows service-specific trajectories instead of technological ones (e.g. Gallouj, 1991; Preissl, 2000; Sundbo, 1998). The third approach, which is now increasingly gaining ground, is the synthesis or integrative approach, which seeks a common framework for the analysis of innovation in both goods and services without denying, however, the existence of some differences between them (Bröchner, 2006; Gallouj and Weinstein, 1997; Gallouj, 2002; Sundbo, 2001; de Vries, 2006; Windrum and Garcia-Goni, 2008). 
This paper aims to contribute to the further development of the synthesis approach. We argue that goods and services can be analysed using a common conceptual framework, but highlighting within this framework the process nature of services. The conceptual framework that we elaborate in this paper is the characteristics-based model developed by Gallouj and Weinstein (1997), following Saviotti's and Metcalfe's work (1984). In such a model the product (whether it is a good or a service) is the conjunction of vectors of characteristics and of competences: service characteristics [Y], technical characteristics [X], provider competences $[\mathrm{C}]$ and client competences [ $\left.\mathrm{C}^{\prime}\right]$. Our hypothesis is that the process dimension is not visible in this model which is likely to reduce its operational validity. The purpose of this paper is therefore to improve the characteristic-based approach and to make the service process more visible.

We first analyse the content of the different characteristics categories in the original Gallouj-Weinstein model and summarise the innovation types recognised on the basis of the model. Thereafter we describe the results of the applications of the model from the theoretical viewpoint and consider the modifications and extensions made in the literature. Then we present our suggestion for a supplemented version of the model. In the fourth part of the paper, we apply the supplemented model in two empirical cases: 1) 'workplace design' provided by architect's offices and 2) 'fifty plus' services provided by insurance companies. We have studied the cases in depth at the company level in Finland, but both of them reflect service innovations that have spread internationally.

\section{The characteristics-based service innovation model and its applications}

\subsection{The original model}

When transferring the characteristics-based model from the context of goods to the context of services, Gallouj and Weinstein (1997) stated that extending the notion of final characteristics (Y) to services does not pose any conceptual problem. Both goods and services provide clients with benefits that can be described in terms of quantity, quality, easiness of access, later applicability etc. As regards technical characteristics (X), Gallouj and Weinstein made a distinction between tangible and intangible ones. The former contain the same basic elements that Saviotti and Metcalfe (1984) had included in the technical and process characteristics of goods: the tangible technical characteristics of the (service) product and the tangible technologies used in its design, production and marketing. In the case of services, information and logistics technologies are typical examples of these kinds of characteristics. The latter consist of the expertise and the non-technological models and methods applied in the production of the service. Finally, Gallouj and Weinstein mention organisational and spatial characteristics as possible elements of technical characteristics.

Gallouj and Weinstein solved the difficulty of distinguishing between technical and process characteristics in services by interpreting these two groups of characteristics as one and the same thing. In other words, they included all the tangible and intangible forms of the service process among technical characteristics. They pointed out that technical characteristics contain both the front-office and back-office technologies and processes.

Gallouj and Weinstein added a new group of characteristics: competence characteristics (C). Each technical characteristic mobilises certain competences. The addition of the competence category is necessary because the provision of a service is the result of two competence-related mechanisms: the utilisation of technical characteristics that are themselves based on competences, and the direct mobilisation of competences. In addition to the competences of the service provider, the competences of the client (C') are included in the model, this being the way in which the co-production relationship typical of services is taken into account. Figure 1 presents the model in its original form. 
Figure 1 to be inserted here

Gallouj and Weinstein defined innovation as any change affecting one or more of the above described characteristics. They specified different types of innovations based on their model. Radical innovation means that a totally new system of $\left[\mathrm{Y}^{*}, \mathrm{X}^{*}, \mathrm{C}^{*}\right]$ replaces the old one. Improvement innovation is created when the value of a certain $\mathrm{Y}_{\mathrm{i}}$ is increased by improving certain $\mathrm{X}_{\mathrm{j}}$ or certain $\mathrm{C}_{\mathrm{p}}$. Innovation by addition or substitution occurs when one or more new elements are added to vector (Y), or one or more of its elements are replaced. This generally involves the addition of new elements to vector (C) and (X) or the replacement of some of their elements. Ad hoc innovation refers to a situation where a tailor-made service originally provides benefit (Y) to one client only, but includes elements that can be formalised afterwards in $\mathrm{C}$ and $\mathrm{X}$ and hereby used generally. Recombinative or architectural innovation takes place when a new service is developed either by combining characteristics of two or more existing services (bundling), or by splitting up an existing service (unbundling). Finally, the benefit provided by a service can be increased through formalisation innovation, which refers to increasing the visibility and concreteness of the service; this can be achieved by putting the competence, technical and final characteristics 'into order' and by clarifying the relationship between them.

\subsection{The model supplemented with new groups of characteristics}

There are two important studies that have supplemented the original Gallouj-Weinstein model with new groups of characteristics: De Vries (2006) and Windrum and Garcia-Goni (2008).

According to de Vries, two trends in innovation require enhancement of the original Gallouj-Weinstein model: the delivery of bundles of products and services by networks of providers, and provider-customer contact and co-production through technological channels (internet, cellular telephony etc.). Regarding the latter, a particularly important fact is that customers increasingly use their own technology (technical characteristics) in addition to, or instead of, the provider's technology when contacting the provider. The development of ICT has essentially increased the importance of the customer's technology, but there are also other types of technologies which should be considered from the viewpoint of both the provider and the customer; de Vries mentions logistics technology as an example.

De Vries emphasises that network-based services cannot be described through multiple usage of the Gallouj-Weinstein model, because this would not enable representing the interactions between the different types of characteristics of different service providers. Yet, it is just these interactions which are essential in network organisations and offer opportunities for innovations. The revised model also includes the idea that customers may co-produce not only with one, but with several providers.

In the present paper, we adopt the idea of including the customer's technical characteristics in the model. However, even though the network perspective is very relevant too, we restrict ourselves to studying the relationship between one provider and one customer in order to illustrate clearly enough our main point, which is the process nature of the service.

Like de Vries, also Windrum and Garcia-Goni (2008) point out that innovations are developed and selected in a multi-agent environment. They want to develop a framework which captures the key groups that are involved in innovation processes and exert an important influence on the evolution of innovations. In particular, the authors want to take into account the role of policy makers and public sector service providers in addition to firms and customers. The model adopts from the original Gallouj-Weinstein representation the competence characteristics and the final characteristics. Competence characteristics are interpreted very broadly: they also include the technical and process characteristics. While dispensing with a separate category of technical characteristics included by Gallouj- 
Weinstein, the model introduces a new category of preferences (interests). The preferences describe the selection environment of innovations which determines their success or failure. The preferences, as well as competences, are linked to three different types of actors: service provider, user (customer) and policy maker.

As a result of these modifications, the framework no more describes the characteristics of a service product, but the characteristics of the actors involved in the innovation process. In that sense, it goes to the opposite direction - to a more general level - compared with our present effort, which tries to go deeper into the details of the service product. As the authors themselves state, their work has linkages to the innovation systems thinking, which comprises interactions between economic, social and political spheres. In this framework, 'service products are the medium through which different agents communicate their preferences and competences' (Windrum and Garcia-Goni, 2008, p. 668).

There is, however, one important new solution in Windrum's and Garcia-Goni's model which corresponds to our aims: the 'front office - back office' separation. The authors adopt this separation in the form presented by Barras (1986), which means that it focuses on the competences of the service provider. These competences are divided into 'back office' competences and competences needed in face-to-face discussions with clients or users. Because Barras, as well as Windrum and Garcia-Goni include in competences also technical characteristics, the division concerns the major part, if not the whole service at the provider's side. The 'user facing' competences are specified here to include all the tangible and intangible skills, know-how and technologies mobilised by service providers when interacting with their users in order to define, produce and deliver the final service. Except the lacking attention to the process characteristics, this specification is well in line with our view. Further, defining the competences broadly and linking them to all types of actors mean that Windrum and Garcia-Goni implicitly include technical characteristics, not only in the case of the provider, but also in the case of the customer (even in the case of the policy maker) - the point that deVries makes explicit and highlights in his model. However, they do not apply the of 'front office - back office' distinction to the customers.

\subsection{The model supplemented with an analysis of the service media, corresponding operations and technologies, and innovation trajectories}

In 2005, Djellal and Gallouj developed a new variation of the characteristics-based model in order to analyse complex systems with various constituent services. As regards innovation, this variation does not concentrate on adding/subtracting vectors, i.e. groups of characteristics, to the model but provides an alternative way to analyse service technologies and processes and their dynamics. Instead of the category of technical characteristics (including process characteristics), Djellal and Gallouj adopted as a new variable the media of service provision, with corresponding operations and technologies. Because the framework was planned for the analysis of complex systems, the constituent services are included as another new variable. From the original Gallouj-Weinstein representation, the provider's competence characteristics and the final characteristics are adopted as such into the new model. The model is presented in a form of a table where the vertical axis describes the constituent services and the horizontal axis comprises the competences, service media and final characteristics. Djellal and Gallouj originally developed this renewed model in the hospital context, being able to show that there is lot of space for many types of innovations in many types of services (cleaning, catering, recreation, management etc.), not only in the medical treatment or nursing care. Later, the model has been generalised to be applicable in all 'assembled-type' services, i.e. services that are packages of constituent services (Djellal and Gallouj, 2008a), and it has been examined in detail in large scale retailing (Gallouj, C., 2008) and in the building and construction sector (Bröchner, 2006). 
From the viewpoint of the present paper, the most important aspects of this renewed model are included in the analysis that starts with the introduction of the media and targets of service provision. In accordance with the notion of the service triangle (Gadrey, 1996), Djellal and Gallouj suggest that the provision of a service consists of a set of operations affecting various media or targets, namely material objects (M), information (I), knowledge (K) or individuals (R). Thus four groups of operations can be identified (Gadrey, 1996; Gallouj, 1999) which are combined in differing proportions each time the service is provided: 1) material transformation operations (M), 2) information processing operations (I), 3) operations involving the intellectual processing of knowledge $(\mathrm{K})$, and 4) contactual or relational service operations $(\mathrm{R})$. The nature of these operations differs depending on the type of target. In the first case, the targets are tangible objects that have to be processed in some way, i.e. transported, transformed, maintained, repaired etc. In the second case, it is codified information that has to be produced, captured, diffused, stored or revealed. In the third case, the processing is based on codified methods and routines and intangible technologies. The fourth case, in which the main medium is the customer, involves the provision of a direct service with a greater or lesser degree of interactivity with the customer. Each of these groups of operations can be associated with particular families of technologies. This is particularly evident in the case of the first three groups of operations, which correspond, respectively, to material processing technologies, information processing technologies and cognitive technologies.

The analysis of innovation on the basis of the model starts from the identification of the organising principles that can change either the variable of constituent services or the variable which consists of competences; media, corresponding operations and associated technologies; and final characteristics. According to Djellal and Gallouj, there are four organising principles that can drive innovation in this framework: extensive, regressive, intensive and combinatory. The extensive principle means that new constituent services are added to the existing service, and the regressive principle involves the elimination of constituent services. The intensive principle means that new competences and/or (tangible or intangible) technologies are added, a process that may be accompanied by the elimination of old competences and/or technologies. Also the value of existing competences and/or technologies might be increased or reduced. Within this intensive organising principle, four innovation trajectories can be identified. These trajectories correspond to the different types of operations included: a material transformation trajectory, an information processing trajectory, a methodological and cognitive trajectory, and a relational trajectory. The fourth principle driving innovation - the combinatory principle - is the most common according to Djellal and Gallouj. It draws on the basic mechanisms outlined above, which it links in number of different ways.

We will utilise Djellal and Gallouj's discussion of different technologies and operations when specifying the technical and process characteristics in our model.

\section{Making the process nature of services more visible in the model}

\subsection{Basic ideas for a supplemented model}

In this section we present our modification of the original Gallouj-Weinstein model in order to try and make visible the process nature of services. For this purpose, we introduce three new aspects into the original model: 1) we adopt a specific category for the process characteristics, i.e. we separate them from the technical characteristics, 2) we adopt the division between 'front office' and 'back office' which we apply to all groups of the provider's characteristics, and 3) we include in the model the customer's characteristics, not only in the case of competences, but also in the case of technology and process, and apply the 'front office - back office' division also to these characteristics. Our focus is on the separate category for process characteristics, but we think that its illustration requires the 'front office - 
back office' division and a versatile representation of the customer's characteristics in order to achieve clarity.

Gallouj and Weinstein suggested in their original model that a division between the technical and process characteristics could be made by linking the technical characteristics to the 'front-office' and the process characteristics to the 'back office'. An aim to find an analogy with goods is apparent in this suggestion: in goods the production process is usually not visible to the clients, and what is visible is the good itself. Thus, in goods it is natural to link the process characteristics to the 'back-office' and the technical characteristics to the 'front-office'. Applying this view to services, even though it would enable a nice parallel with the model of Saviotti and Metcalfe (1984), is difficult as it leads to naming as process characteristics those parts of the service that are outside the client interaction. While this result is against the unanimously stated importance of client participation in services, turning around the idea - linking all process characteristics to the 'front office' and all technical characteristics to the 'back office' - does not work either. Evidently there are processes that prepare client interactions outside the client's view ('back office') and there are technologies mobilised in actual interactions ('front office').

Thus, we give up solutions which would locate all technical characteristics on one side and all process characteristics on the other side of the client interface. Instead, we make $a$ division within technical, process and competence characteristics, dividing them into those actually mobilised in the client interaction and those preparing or being based on this interaction. We call the former 'front-office' characteristics and the latter 'back-office' characteristics. This way of interpreting the discriminatory function of the client interface corresponds well to writings of the authors who have profoundly discussed the 'front office back office' division, without applying, however, the characteristics-based approach (e.g. Silvestro et al., 1992). Compared with the original Gallouj-Weinstein model, our solution means a greater detachment from the thoughts by Saviotti and Metcalfe, i.e. it depicts the special nature of services. However, we want to emphasise that it still enables the analysis of both goods and services using the same basic characteristics (synthesis perspective).

In addition to the solutions aiming to increase the visibility of the service process, we include in our model the division between direct and indirect final characteristics. The former refer to utilities that manifest themselves during the service process, whereas the latter are utilities that manifest themselves in the longer term. We consider this division important at least in some types of services (for example public services), and especially for performance definition and measurement (Djellal and Gallouj, 2008b). Our modified model in a general form is presented in Figure 2.

Figure 2 to be inserted here

Corresponding to the original Gallouj-Weinstein representation, (Y) refers to the final characteristics of the service. We use the symbol $\left(\mathrm{Y}_{\mathrm{d}}\right)$ to refer to the direct (immediate) utilities and the symbol $\left(\mathrm{Y}_{\mathrm{i}}\right)$ to refer to the indirect (longer-term) utilities. (X) refers to the technical characteristics and (C) to the competence characteristics of the provider. The provider's process characteristics are introduced as a new vector (Z). The characteristics $(\mathrm{X})$, $(\mathrm{Z})$ and $(\mathrm{C})$ are divided to 'front office' characteristics, denoted by the subscript FO, and to 'back office' characteristics, denoted by the subscript BO.

On the customer's side, (C') refers to the competence characteristics of the customer, and the original representation has been supplemented with technical and process characteristics (respectively (X') and (Z')), i.e. the same framework of characteristics has been applied throughout both in the case of the service provider and the customer. As regards the customer's technical characteristics ( $\left.\mathrm{X}^{\prime}\right)$, their inclusion is justifiable at least in the cases 
where customers contact their service providers or more generally interact with them using their own ICT devices - a point emphasised by de Vries (2006). The customer's process characteristics (Z') are essential for the illustration of the fact that in many cases customers participate in the production process of the service.

In Figure 2, we have not indicated all the relationships between the different vectors in order to simplify the representation. It should be noted that these relationships can have different meanings (mobilisation of resources, consubstantiality, interaction, etc.), and that the general representation of Figure 2 encompasses several particular service cases and cases including both goods and services (self-service; 'pure' service with or without coproduction; services related to goods, i.e. industrial services; etc.).

\subsection{Contents of the different characteristics groups}

The category of the provider's process characteristics $(Z)$ in our model has a more limited content compared with Saviotti's and Metcalfe's (1984) definition of process characteristics in manufacturing. What is common is the inclusion of all stages of the process within this group of characteristics: design, marketing and actual production. In services these stages often coincide. Design continues in actual production, where the service gets its final shape as a result of the customer-provider interaction (Edvardsson et al., 2006; Lusch et al., 2007; Sundbo and Gallouj, 2000; Toivonen et al., 2007; Ulwick, 2002). In marketing, some separate efforts are often done, but the linkage to production exists: Sundbo (1994) has pointed out that the co-production situation provides a very special possibility for personal marketing combined with fulfilment of needs of the individual customer. All this emphasises the importance of 'front office' process characteristics in services. However, there are also significant processes in the 'back office': preparations for the customer interaction and activities based on this interaction, e.g. processing material and information concerning the service in question, and handling the customer feedback.

After separating the process - the genuine acts - from the technical characteristics, there remain two types of characteristics in this category $(\mathrm{X})$. The first group reflects maybe most clearly the product nature of the service (in the usual sense of the word). It includes in the 'back office' the basic idea of the service in question - the service concept and the prototype of the process. In the 'front office' it includes the concrete results in those cases where the result is separable from the utility - as an example can be mentioned an insurance document (result) that guaranties a certain amount of safety (utility). Other examples are a legal document or a research report (results), which contain utilities for legal protection or strategic actions, or software (result), which allows different functions (utilities). The second group can be called 'enablers'; it includes the technology (in the narrow sense) as well as the nontechnological methods and models used in the service production. Further, it includes the organisation and spatial characteristics. In this group, the 'front office' characteristics are partially mobilised expressions of the corresponding 'back office' characteristics. However, there are also technologies and models, as well as organisational and physical elements, that serve 'back office' operations, e.g. book-keeping software, manuals for personnel training, administrative parts of the organisation, and the ergonomics of the work environment. Our solution to locate the 'enablers' in the category of technical characteristics clearly deviates from the analysis of a good by Saviotti and Metcalfe, where the 'enabling type' characteristics were seen as a part of the production process. However, in services the inclusion of the 'enablers' in the process characteristics would lead to broadening the concept of the service process in a way which is unfamiliar in service literature, irrespective of the school of thinking.

The service concept and the prototype of the process deserve some further comment. They were not explicitly mentioned in the original Gallouj-Weinstein model; yet, they are an 
essential part of the intangible technical characteristics of a service. The service concept includes the basic idea of the service in question as well as its structure and role in the total offering of the provider organisation (Edvardsson, 1997). The concept is based on an understanding of the customer needs and how these needs can be fulfilled. This understanding may be in the form of tacit knowledge, or it can be clearly expressed in the form of a service promise which describes the utilities (Y) to be provided. An advanced service concept also includes the analysis of the structure of the service: a division into the core and the supporting elements (Grönroos, 1990) and, along with the increasingly common practice of modularisation, also the service modules (Sundbo, 1994). The prototype of the process is closely linked to the service concept. Since the beginning of the 1980s, specific instruments have been developed in order to systematise the design of the service process. For instance, blueprint diagrams where processes are drawn as boxes and lines have become widespread (Shostack, 1984; Fliess and Kleinaltenkamp, 2004). Blueprints illustrate the service in question both from the viewpoint of the provider (the provider's process) and from the viewpoint of the customer (the customer's process), and they also depict the points where the processes coincide (the interface).

As mentioned earlier, our definition of competence characteristics (C) is in line with the thoughts of Windrum and Garcia-Goni (2008), but focuses on 'pure' competences instead of including technical characteristics in the same group (the solution of Windrum and GarciaGoni). The introduction of 'front office - back office' division also enables an additional clarification to the original Gallouj-Weinstein model. In this model, the vector C included only the individuals' or small groups' competences implemented directly in service transactions, and the organisation-level competences were located within intangible technical characteristics. We consider it more consistent to interpret also the latter - i.e. competences linked to organisational learning and organisational memory - as genuine competence characteristics, belonging to the 'back office'. As regards the 'front office' competences, we keep the original Gallouj-Weinstein definition, including in them all the individual and smallgroup skills and know-how mobilised in the real life service delivery. Corresponding to the case of technical characteristics, some individual competences are also mobilised directly in the 'back office'. For instance, the use of CRM (customer relationship management) systems requires its own specific skills.

Gallouj and Weinstein mentioned cognitive, creative, operational and relational competences as examples of competence characteristics. Another useful categorisation has been made by Kuusisto (2000), who divides competences and skills needed in service production into three levels: business level, service process level and personal interaction level. Toivonen (2004) has specified the contents of these categories in more detail. According to her, business level skills include understanding the basics of economy and business, understanding the on-going changes, and overall management of one's own value chain. Skills needed at the service process level cover mastering the contents and methodology of one's own sector, know-how concerning client industries, and management of actual service processes. Finally, the personal interaction level requires marketing and sales skills, cooperation skills, and social and personal skills. We can add to this that business skills seem to be mainly of 'back office' type, interaction skills are most critical in the 'front office', and process skills are needed in both. Table 1 summarises our analysis of the contents of the characteristics groups $(\mathrm{X}),(\mathrm{Z})$ and $(\mathrm{C})$.

Table 1 to be inserted here

Until now we have concentrated on the characteristics of the service provider. An equally detailed discussion of the characteristics of the customer is not possible in the limits of this 
paper, but we highlight the points that we consider most important. First and foremost it should be noted that the 'front office - back office' division is relevant, not only in the case of the service provider, but also in the case of the customer: customer characteristics are only partially visible to the provider. As regards the process characteristics of the customer ( $\left.Z^{\prime}\right)$, researchers have used the term 'customer journey' or 'customer path' to describe the particular ordering of customer activities (Gummesson and Kingman-Brundage, 1992). The steps on this 'path' have been categorised in different ways; for instance, Whittle and Foster (1989) identify six main steps: search, arrival, pre-contact, contact, withdrawal and follow-up. Among the customer's technical characteristics ( $\left.X^{\prime}\right)$, we have already mentioned - based on the article of de Vries (2006) - the importance of the technology that the customer uses when contacting the provider or interacting with him. However, we have to add that the customer may also use in this contact non-technological models and methods, which exist on the customer's side as well as on the provider's side (especially in the case of business customers with large internal service departments). Further, the customer's organisation may play a significant role in the realisation of a service. Among the competence characteristics of the customer (C'), particularly important are the ability to make correct assessment of one's own needs and situation, communication skills for 'educating' the service provider, decision making skills, and the ability to evaluate the service quality. In addition, in the cases of a strong co-production relationship, customers have to possess the skills associated with the fulfilment of tasks in the service delivery. Performing concrete service-specific tasks is needed in self-services too, but instead of cooperation the focus is here on the ability to operate independently of the provider (Chervonnaya, 2003).

\section{Applying the supplemented model in empirical cases}

In this section, we apply our modification of the Gallouj-Weinstein model in two empirical cases: 1) 'workplace design' provided by architect's offices and 2) 'fifty plus' services provided by insurance companies. The first case represents knowledge-intensive business services (KIBS) that expert companies provide to other companies and organisations and the second consumer services, i.e. services offered to individuals and households. The empirical material has been gathered in Finland; we have studied each service in one company using interviews and company workshops as research methods. In the following analysis, we describe each of the two services before and after innovation, identify the characteristics that have changed, and examine the type of innovation(s).

\subsection{Case 1: 'Workplace design' provided by architects}

'Workplace design' is an approach which highlights the integration of architectural design with the client's overall strategic direction. Workplaces are seen as a strategic asset, and the aim is to create workplaces that support and enhance the client's business. According to workplace specialists, the fulfilment of this aim is achieved in several ways. Spaces can be used as a means to increase productivity on one hand and to stimulate employee satisfaction on the other. Spaces can also be used to reinforce organisational identity: architecture reflects organisational culture and the company's way of doing business. Further, changes in the workplace layout are a concrete way to support the changes that an organisation wants to make in its strategy and operations (Chan et al., 2007). 'Workplace design' usually starts with a visioning session with the top management of the client. Thereafter representatives of the architect's office spend an intense one- to two weeks' period on-site, gathering information and developing recommendations for the design together with the client. The methodological repertoire is versatile compared with traditional architecture. For instance, behavioral observations and on-line social network surveys are applied in the examination of work processes and the use of spaces (Kampschroer et al., 2007). 
'Workplace design' has focused on developing architectural solutions that take into account the specific requirements of knowledge work, which tends to be more team-based and collaborative. In addition, the rapid rise of the internet and various other communication tools has made work more mobile. The proponents of 'workplace design' argue that the physical space in which work occurs should change hand in hand with changes in the organisation of work.

We have studied the application of 'workplace design' in a Finnish architectural company, which has been one of the pioneers in the development of this service in Europe, starting the first 'experiments' with the new approach at the end of the 1980s. Nowadays 'workplace design' is a formalised service product in the company. It has a modular structure and it includes an explicitly expressed service promise: 'workplace service helps the clients to make their work processes more efficient via the development of office spaces'. The case company is well aware of the international models and methods used in 'workplace design', and it has developed some of them further. Workshops as a tool are emphasised in particular: common, profound discussions about future office layout makes the employees committed to changes they feel that their opinions are appreciated. The interviewees in the company emphasised the essential change that 'workplace design' had brought with it to architect's service: architectural expertise has to be supplemented with know-how in management consultancy.

After the general description above, we now examine 'workplace design' using the characteristics-based analysis (Table 2). When comparing 'workplace design' with the traditional architect's service, we find changes in all characteristics groups. The most important changes are the increase of front-office tasks among both the provider and the client, and the general activation of the client's role.

Earlier architect's offices concentrated on making plans that corresponded to the order of the client $(\mathrm{Z})$. The technical characteristics (X) as well as competences (C) were focused narrowly on architecture-specific methods, technology and know-how, and the service provider met the client quite rarely - in the original negotiations and in the presentations of drawings. The client's organisation was usually not broadly involved in the design process. After selecting the architect, the interaction (Z') was delegated to a contact person/group. Competences required from the client included the ability to somehow evaluate and communicate space needs and to make decisions based on the architect's proposals (C').

The 'workplace design' approach means continuous interaction between the service provider and the client, i.e. the service is co-produced. This co-production relationship is clearly manifested in the increase of 'front-office' activities in the service process. The service provider spends time in the client's premises, making observations and organising workshops $\left(\mathrm{Z}_{\mathrm{FO}}\right)$, where the client's personnel broadly participates $\left(\mathrm{Z}_{\mathrm{FO}}^{\prime}\right)$. The general activation of the client's role means that also its 'back office' tasks have increased: the client has to analyse in detail its strategies, work processes and the related space needs ( $\left.Z{ }^{\prime}{ }_{\mathrm{BO}}\right)$. The changes in the process require changes in competences. Instead of a single profession, architect's offices have to become multidisciplinary - recruiting behavioural, management and business experts $\left(\mathrm{C}_{\mathrm{BO}}\right)$. Clients have to develop their strategic abilities and readiness for changes $\left(\mathrm{C}^{\prime}{ }_{\mathrm{BO}}\right)$. 'Workplace design' implies changes in technical characteristics too. Concerning the service provider, essential changes are a clear service concept and multiple methods $\left(\mathrm{X}_{\mathrm{BO}}\right)$, as well as versatile reporting $\left(\mathrm{X}_{\mathrm{FO}}\right)$. On the client's side, more organisational resources have to be allocated for space issues than before. Finally, internet technology plays an important role in the service, as surveys of space users' opinions are usually carried out online $\left(\mathrm{X}^{\prime}{ }_{\mathrm{BO}}\right)$.

'Workplace design' is an example of a service where separating direct $\left(\mathrm{Y}_{\mathrm{d}}\right)$ and indirect $\left(\mathrm{Y}_{\mathrm{i}}\right)$ utilities is useful. The inclusion of a futures perspective is essential in this approach, and is reflected in striving for flexibility, variability and sustainability in space solutions, i.e. 
striving for indirect utilities that may be realised after years or even decades later. Even though these viewpoints have been present in traditional architecture too, in practice they have often been trampled by short-term economic goals (Chan et al., 2007). The fact that indirect utilities are taken more seriously in 'workplace design' is shown by our interviewees, who told that they accept only assignments where a long-term perspective is included.

Table 2 to be inserted here

The innovations included in 'workplace design' are first and foremost innovations by addition or substitution. In the analysis above we have identified several new elements in technical $(\mathrm{X})$, process $(\mathrm{Z})$ and competence $(\mathrm{C})$ characteristics (internet surveys, workshops and multidisciplinarity serving as examples) which lead to new direct and/or indirect utilities $\left(\left(\mathrm{Y}_{\mathrm{d}}\right),\left(\mathrm{Y}_{\mathrm{i}}\right)\right)$. In addition, the movement of architectural practice towards management consultancy means that some earlier elements have been substituted with new ones: for instance, instead of 'drawings' a significant part of results are presented in a written form. A second innovation type that manifests itself in 'workplace design' is innovation by formalisation. Simplifying a little, we can say that in traditional architecture the provider sells experts' working hours, whereas in 'workplace design' the entity sold is a clearly structured service product with explicitly stated utilities.

As regards the proceeding of the innovation process, the interviewees of our case company reported that the process started from front-office technical characteristics $\left(\mathrm{X}_{\mathrm{FO}}\right)$ : from the observation methods adopted abroad. Developing methods for data analysis in the 'back office' $\left(\mathrm{X}_{\mathrm{BO}}\right)$ was a natural next step. Strategy linkage $\left(\mathrm{Z}_{\mathrm{BO}}\right)$ and the co-production practice $\left(\mathrm{Z}_{\mathrm{FO}}\right)$ - issues linked to process characteristics of 'workplace design' - were the next developmental targets. At the final stage the development focused on competences, first in the 'back office' (multidiciplinarity) $\left(\mathrm{C}_{\mathrm{BO}}\right)$ and then in the 'front office' (change agent competences) $\left(\mathrm{C}_{\mathrm{FO}}\right)$. Thus, the following sequence of stages $\mathrm{X}_{\mathrm{FO}} \ldots \mathrm{X}_{\mathrm{BO}} \ldots \mathrm{Z}_{\mathrm{BO}} \ldots \mathrm{Z}_{\mathrm{FO}} \ldots \mathrm{C}_{\mathrm{BO}}$ $\ldots \mathrm{C}_{\mathrm{FO}}$ describes the innovation process in this case.

\subsection{Case 3: 'Fifty plus' services provided by insurance companies}

Since the 1990s, both researchers and practitioners have paid attention to the growing senior market - adults who are over 50 or 55 years old. The reason for this attention lies in changing demographic trends: in all Western countries, people being retired or approaching the age of retirement form a much bigger proportion of the total population than in earlier decades. The development of services that are functional and attractive to mature consumers is a challenge, but also an opportunity. It is topical not only in healthcare, but also in sectors like travel and leisure, retail, sports, and financial services. An important point that service providers often forget is that the 'greyhairs' are not a homogenous group. The lengthening of life expectancy means that the group includes people in very different lifestages, and this leads to a considerable variety of service needs (Carrigan, 1998; Djellal and Gallouj, 2006).

Some studies indicate that the opportunities of the 'grey market' have been recognised in financial services (banking and insurance) more slowly than in other sectors (Kennett et al., 1995). Officials in financial services typically do not discuss concretely and comprehensively the changes that retirement causes in clients' economic circumstances. Attitudes are also a problem: stereotypes concerning ageing are common, particularly among young service personnel. If the official and the client are of approximately the same age, mutual understanding is usually easier to achieve.

We have gathered empirical material from a Finnish company which has integrated insurance and banking businesses. We focus particularly on a new service which aims to map 
the service needs of those clients who have recently retired or are going to retire in the near future. The service is carried out as one hour face-to-face discussion with the client, and it is planned to cover the most important issues which may influence the economic security of the client in his/her new stage of life. These issues include, for instance, how to organise health service when occupational health service ends, and how to get by on one's pension if there are loans to be paid. The service is free of charge and it does not put the client under the responsibility of purchasing new insurance products, increasing savings etc. However, the discussion often reveals gaps or overlaps in the client's insurances, deposits or loans, and in this way leads to seeking solutions which may benefit the service provider.

Some needs mapping service has been available in our case company for years, but it has been general in nature, i.e. it has not taken into account the differences between age groups. According to the interviews, the new 'fifty plus' service is actually the first one where the needs linked to specific lifecycle stages form the starting point, and it may lead later to the adoption of corresponding services for other age groups. The development of the mapping service goes hand in hand with the development of insurance products for 'fifty plus' clients. The interviewees told that the lack of suitable products has been one reason which has delayed the launch of the new service. Applying the general mapping service for specific client groups has been difficult because of its unsystematic nature. As the organisation has lacked a clear division of work, the mapping service has belonged to the service repertoire of all officials, who have carried it out in their own ways - the time used has varied from five minutes to one and half hours. Well versed employees have actually provided very good service based on intuition and tacit knowledge, but more inexperienced employees have been confined to those issues that the clients have explicitly asked or desired. Thus, the mapping service for seniors goes hand in hand, not only with product development, but also with the development of the division of work. Short service encounters have now been clearly separated from longer sessions that are based on appointments. The former answer the client's acute problems and the latter are intended for more profound analysis of the client's situation. Officials providing profound service are qualified financial advisors.

Using our modified characteristics model, we can describe the general mapping service as follows (see Table 3). The service process starts from the initiative of the client or the official. The client may have seen an advertisement for the mapping service in the internet and makes an appointment, or the official suggests an appointment as a part of some campaign; he/she may also offer the service as a continuation for the treatment of some acute issue of the client $\left(\mathrm{Z}_{\mathrm{FO}}\right)$. In the case of an appointment, both the official and the client prepare themselves for the session by gathering available documents and other information $\left(\left(\mathrm{Z}_{\mathrm{BO}}\right)\left(\mathrm{Z}{ }_{\mathrm{BO}}\right)\right)$. The session takes place in a separate, peaceful room, because the topics of discussion are often intimate. A specific tool is used for calculations concerning the client's social security (e.g. the amount of future pension or sickness benefits). Based on these calculations, the client can make financial plans and solutions regarding insurances and savings, either in the same session or after familiarisation with the report that the official prints out ( $\left.Z^{\prime}{ }_{\mathrm{FO}}\right)$. The calculation can also be made as a self-service in the internet. The officials get many types of support for their work - there are guidebooks, initiation, and intranet material for continuous learning $\left(\mathrm{X}_{\mathrm{BO}}\right)$. Discussions to be carried out in client sessions have been modelled, and question techniques and the direction of conversations have been practised $\left(\mathrm{X}_{\mathrm{FO}}\right)$. However, all this has focused on general knowledge concerning insurance products and client interaction; issues linked to specific groups of clients have not been included.

In the new age-specific service (see Table 3), the activity is based on a service model, which has been designed for 'fifty plus' clients. The stages of the process and the tasks of the client remain mostly as before, but the content of the discussion changes, which implies changes in technical characteristics and particularly in competences. A clear service concept 
$\left(\mathrm{X}_{\mathrm{BO}}\right)$, which is also expressed in the form of a service promise, is a big change. The service focuses clearly on the issues that are typically linked with ageing (e.g. ending of some types of insurance). The existing calculation tool has been developed to take into account these specific issues. A check list of essential questions facilitates the official's work during the session and guarantees service of uniform quality $\left(\mathrm{X}_{\mathrm{FO}}\right)$. The service is appointment-based and the time allocated for it is fixed (one hour). In its present form, the service relies on faceto-face interaction, but self-service via the internet is under consideration. The information that the client gets as the result of the service session is more versatile and more topical than before. The new competences required from the service personnel concern both attitudes and facts $\left(\mathrm{C}_{\mathrm{BO}}\right)\left(\mathrm{C}_{\mathrm{FO}}\right)$. The development of competences is supported in many ways: there are new directions, new courses, and new learning material in the intranet. According to the interviewees, it is particularly important to avoid stereotypes and show flexibility when serving seniors of different age and background. Factual knowledge concerns matters that clients have to take up before and after retirement and in the years following it. Factual knowledge about suitable service products is also needed. The interviewees told that the company puts much effort into the development of insurance products that cover the clients' whole lifecycle, including the oldest years. Marketing the new 'fifty plus' service is very active too.

In the utilities, the biggest difference compared to the earlier situation is the emphasis of a long-term perspective $\left(\mathrm{Y}_{\mathrm{i}}\right)$. Before the age-specific mapping service, seniors received help with their 'here and now' problems in the first place. If longer-term matters were discussed, the discussion took place at a general level. In the new service, acute and immediate service needs are answered too, but in addition the securing of the client's personal economy during the coming years is examined in a comprehensive and detailed manner. When the clients become aware of the details in their social security and other financial issues, they can better prepare themselves for different stages in their mature years.

\section{Table 3 to be inserted here}

When identifying innovation types in the 'fifty plus' mapping service, we find primarily improvement and formalisation. Innovation by improvement is linked to the service provider's competence characteristics in particular: officials have acquired deeper knowledge of the issues linked to senior years. Improved utilities have also been achieved via changes in technical characteristics. The calculation tool and the material that supports the service encounter have been modified so that they take into account the specific needs of older age groups (e.g. the need to compensate the loss of work-related benefits). Even more apparent in the service provider's technical characteristics is, however, innovation by formalisation. A clear concept shows how the utilities are achieved. Also several smaller aspects in the service have been formalised; the fixed length of service sessions and check lists of essential questions are illustrative examples. Further, there seem to be opportunities for innovation by recombination when the new age-specific insurance products become elaborated enough. The mapping service for seniors could then be broadened into a 'fifty plus' package which contains many types of services for ageing people.

Stimuli for the innovation process in our case company were both external and internal. Clients' needs gave a push to changes that already had been recognised as necessary in the inhouse strategy work, on the basis of on-going population trends. The development started from competences linked to understanding the 'grey market' $\left(\mathrm{C}_{\mathrm{BO}}\right)$. Much background work was done before the development of the service was initiated in practice. This background work included familiarisation with the literature, and the utilisation of the company's own market surveys. As the next step, the service was conceptualised and modelled $\left(\mathrm{X}_{\mathrm{BO}}\right)$, and the 
tools needed in the interaction with senior clients $\left(\mathrm{X}_{\mathrm{FO}}\right)$ were specified. Based on the 'backoffice' competences, and on the technical characteristics which concern both 'back and front office', the company then judged itself to be ready to train the competences that the officials need in the 'front office', i.e. in the actual interaction with clients $\left(\mathrm{C}_{\mathrm{FO}}\right)$. The following sequence of stages $\mathrm{C}_{\mathrm{BO}} \ldots \mathrm{X}_{\mathrm{BO}} \ldots \mathrm{X}_{\mathrm{FO}} \ldots \mathrm{C}_{\mathrm{FO}} \ldots\left(\mathrm{Z}_{\mathrm{FO}}+\mathrm{Z}_{\mathrm{BO}}\right)$ summarises the innovation process. We have put the process characteristics in brackets, because the changes here were very small according to the interviewees. This innovation process is similar to what Gadrey and Gallouj (1998) call 'new expertise field innovation', which consists of detecting an emergent field of knowledge and providing consultancy in this field on the basis of the accumulation of knowledge and the codification of methods and processes.

\section{Concluding discussion}

In this paper we have developed further the innovation in services model developed by Gallouj and Weinstein (1997) in order to make the service process more visible. The solution of bundling technical and process characteristics has made it difficult to apply the original model in detailed studies of individual services. The model is too general for the illustration of changes that take place in the steps or content of the new service process. This is problematic because many service innovations concern process characteristics of individual services. The invisibility of the service process is problematic also from the theoretical viewpoint as most scholars define services as an act, an activity or a process (e.g. Gadrey, 1996; Hill, 1977).

In our modified model, we have started from the idea that the client interface and the 'front office - back office' discrimination can be used to illustrate the service process and the separation of process characteristics from technical characteristics. We have divided technical, process and competence characteristics into those actually mobilised in the client interaction and those preparing for or being based on this interaction. The process characteristics include the acts carried out in the actual production and in the design and marketing of the service. The core of these characteristics is in the 'front office' - in the contact between the producer and the customer. The technical characteristics consist of the service concept, the prototype of the process, and concrete results in those cases where the result is separable from the utility. Also the 'enablers' of the process belong to this group: the technology, methods, models, the organisation and the physical environment used in the service production. Here, 'front office' characteristics are often mobilised expressions of the corresponding 'back office' characteristics. As regards competence characteristics, we have included both individual competences implemented directly in service transactions and the organisation-level competences. The latter are typical back-office characteristics.

In their original model, Gallouj and Weinstein took into account the role of clients by including the client's competences as an additional characteristics group. Later de Vries (2006) has supplemented the model with the client's technical characteristics, arguing that clients increasingly use their own technology when contacting the provider or more generally interacting with him. We have adopted these views in our model and gone two steps further: we also examine the client's process and apply the 'front office - back office' division to all characteristics groups of the client - it is reasonable to suppose that the client's technology, activities and competences are only partially visible to the provider. The last component in our model is final characteristics, which we divide into direct and indirect final characteristics.

We have applied our modified model in two innovative services: 'workplace design' provided by architects' offices and 'fifty plus' services provided by insurance companies. We have described each of these services before and after innovation, identified the characteristics that have changed, and examined the types of innovations. The results indicate 
that a distinction between process characteristics and technical characteristics is possible to render in practice when we use the specifications included in our model. The model enables $a$ detailed description of services and the identification of innovations occurred in them.

In this paper we have focused on the analysis of individual services and of the changes that occur in them as a result of innovation. We have also briefly touched the issue of the innovation process from the viewpoint of the service provider. This topic could be examined in more detail in further studies. Our short summaries at the end of each case reveal interesting differences in the innovation process within the service company: changes in technical, process and competence characteristics in the 'front office' and 'back office' may start and proceed in very many ways. The inclusion also of the client's activities in further studies would enable the modelling of different process types identified in service studies: for instance, innovation following a stage-gate approach (Cooper and Edgett, 1996) and innovation favouring rapid application (Toivonen et al., 2007).

\section{References}

Barras, R., 1986. Towards a theory of innovation in services. Research Policy 15, 161-173.

Bröchner, J. (2006). Between services and goods: innovation among construction contractors. CRIC Conference on 'Innovation in services' June 2006, Manchester.

Carrigan, M., 1998. Segmenting the grey-market: the case for fifty-plus "lifegroups". Journal of Marketing Practice: Applied Marketing Science 4 (2), 43-56.

Chan, J.K., Beckman, S.L., Lawrence, P.G., 2007. Workplace Design : A New Managerial Imperative. California Management Review 49 (2), 6-20.

Chervonnaya, O., 2003. Customer role and skill trajectories in services. International Journal of Service Industry Management 14 (3), 347-363.

Cooper, R.G. and Edgett, S.J., 1996. Critical success factors for new financial services. Marketing Management 5 (3), 26-37.

Djellal, F., Gallouj, F., 2005. Mapping Innovation Dynamics in Hospitals. Research Policy 34, 817-835.

Djellal, F., Gallouj, F., 2008a. A model for analysing the innovation dynamic in services: the case of assembled services. International Journal of Services Technology and Management 9 (3/4), 285-304.

Djellal F., Gallouj F., 2008b. Measuring and improving productivity in services: issues, strategies and challenges. Edward Elgar, Cheltenham and Northampton.

Djellal F., Gallouj F., (2006), Innovation in care services for the Elderly, The Service Industries Journal, vol. 26, n³, p. 303-327.

Edvardsson, B., 1997. Quality in new service development: Key concepts and a frame of reference. International Journal of Production Economics 52, 31-46.

Edvardsson, B., Gustafsson, A., Kristensson, P., Magnusson, P., Matthing, J. (Eds.), 2006. Involving Customers in New Service Development. Imperial College Press, London.

Fliess, S., Kleinaltenkamp, M., 2004. Blueprinting the Service Company: Managing Service Processes Efficiently. Journal of Business Research 57, 392-404.

Gadrey, J., 1996. L'économie des services. Repéres, $2^{\text {nd }}$ ed. La découverte, Paris.

Gadrey, J., Gallouj, F., 1998. The provider-customer interface in business and professional services. The Service Industries Journal 18 (2), 1-15.

Gallouj, C., 2008. Innovation in large scale retailing: toward a revisited approach to its organising principles and trajectories. International Journal of Services Technology and Management 9 (3/4), 305-319.

Gallouj, F., 1991. Les formes de l'innovation dans les services de conseil'. Revue d'économie industrielle 57, 25-45. 
Gallouj, F., 1998. Innovating in reverse: services and the reverse product cycle. European Journal of Innovation Management 1 (3), 123-138.

Gallouj, F., 1999. Les trajectories d'innovation dans les services: vers un enrichissement des taxonomies évolutionnistes. Economies et Sociétés, 1, 143-169.

Gallouj, F., Weinstein, O., 1997. Innovation in services. Research Policy 26 (4/5), 537-556.

Gallouj, F., 2002. Innovation in the Service Economy: The New Wealth of Nations. Edward Elgar, Cheltenham and Northampton.

Gallouj F., Savona, M., 2009. Innovation in services: a review of the debate and perspectives for a research agenda. The Journal of Evolutionary Economics, 149-172.

Gummesson, E., Kingman-Brundage, J., 1992. Service design and quality: applying service blueprinting and service mapping to railroad services. In: Kunst, P., Lemmink, J. (Eds.), Quality management in services. Van Gorcum, Assen, pp. 101-114.

Grönroos, C., 1990. Service Management and Marketing: Managing the Moments of Truth in Service Comptetition. Lexington Books, Massachusetts/Toronto.

Hill, T.P., 1977. On goods and services. Review of Income and Wealth 4, 315-338.

Illeris, S. 1989. Services and Regions in Europe. Gower, Aldershot.

Kampschroer, K., Heerwaagen, J., Powell, K., 2007. Creating and Testing Workplace Strategy. California Management Review 49 (2), 119-137.

Kennett, P.A., Moschis, G.P., Bellenger, D.N., 1995. Marketing financial services to mature consumers. Journal of Services Marketing 9 (2), 62-72.

Kuusisto, J., 2000. The determinants of service capability in small manufacturing firms. Helsinki School of Economics and Business Administration. Acta Universitatis Oeconomicae Helsingiensis.

Lusch, R.., Vargo, S., O’Brien, M., 2007. Competing through service: insights from servicedominant logic. Journal of Retailing 83 (1), 5-18.

Preissl, B., 2000. Service innovation: what makes it different? Empirical evidence from Germany. In: Metcalfe, S., Miles, I. (Eds.), Innovation systems in the service economy: measurement and case study analysis. Kluwer Academics Publishers, Boston, Dordrecht and London, pp. 125-148.

Saviotti, P.P. and Metcalfe, J.S., 1984. A theoretical approach to the construction of technological output indicators. Research Policy 13, 141-151.

Shostack, G.L., 1984. Service design in the operation environment. In: George, W., Marshall, C. (Eds.), Developing New Services. American Marketing Association, Chicago, IL.

Schumpeter J. A., 1934. The Theory of Economic Development: An Inquiry into Profits, Capital, Credit, Interest, and the Business Cycle. Harvard University Press, Cambridge, Massachusetts.

Silvestro, R., Fitzgerald, L., Johnston, R., 1992. Towards a Classification of Service Processes. International Journal of Service Industry Management 3 (3), 62-75.

Soete, L., Miozzo, M., 1989. Trade and Development in Services: A Technological Perspective. Maastricht Economic Research Institute on Innovation and Technology (MERIT), Limburg University, Report No. 89-031, Maastricht.

Sundbo, J., 1994. Modulization of service production and a thesis of convergence between service and manufacturing organizations. Scandinavian Journal of Management 10 (3), 245-266.

Sundbo, J.. 1998. The organisation of innovation in services. Roskilde University Press, Copenhagen.

Sundbo J., Gallouj F., 2000. Innovation as a Loosely Coupled System in Services. In: Metcalfe, J.S., Miles, I. (Eds.), Innovation Systems in the Service Economy: Measurement and Case Study Analysis. Kluwer Academic Publishers, Boston, Dordrecht and London, pp. 43-68. 
Tax, S., Brown S., 1998. Recovering and learning from service failure. Sloan Management Review 49 (1), Autumn, 75-88.

Toivonen, M., Tuominen, T., Brax, S., 2007. Innovation process interlinked with the process of service delivery - a management challenge in KIBS. Economies et Sociétés: Economics and Management of Services Series, No. 3, 355-384.

Ulwick, A., 2002. Turn customer input into innovation. Harvard Business Review 80 (1), 9197.

de Vries, E., 2006. Innovation in services in networks of organizations and in the distribution of service. Research Policy 35, 1037-1051.

Whittle, S., Foster, M., 1989. Customer profiling: getting into your customer's shoes. Management Decision 27 (6), 27-30.

Windrum P., Garcia-Goni, M., 2008. A neo-Schumpeterian model of health services innovation. Research Policy 37, 649-672. 
Fig. 1. The characteristics-based model by Gallouj and Weinstein (1997) in its original form

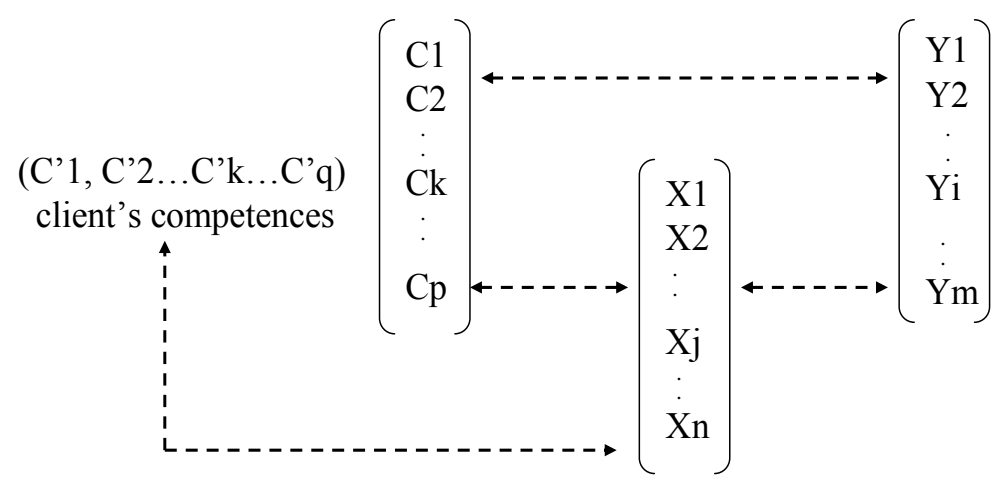

Fig. 2. A revised characteristics-based model of services

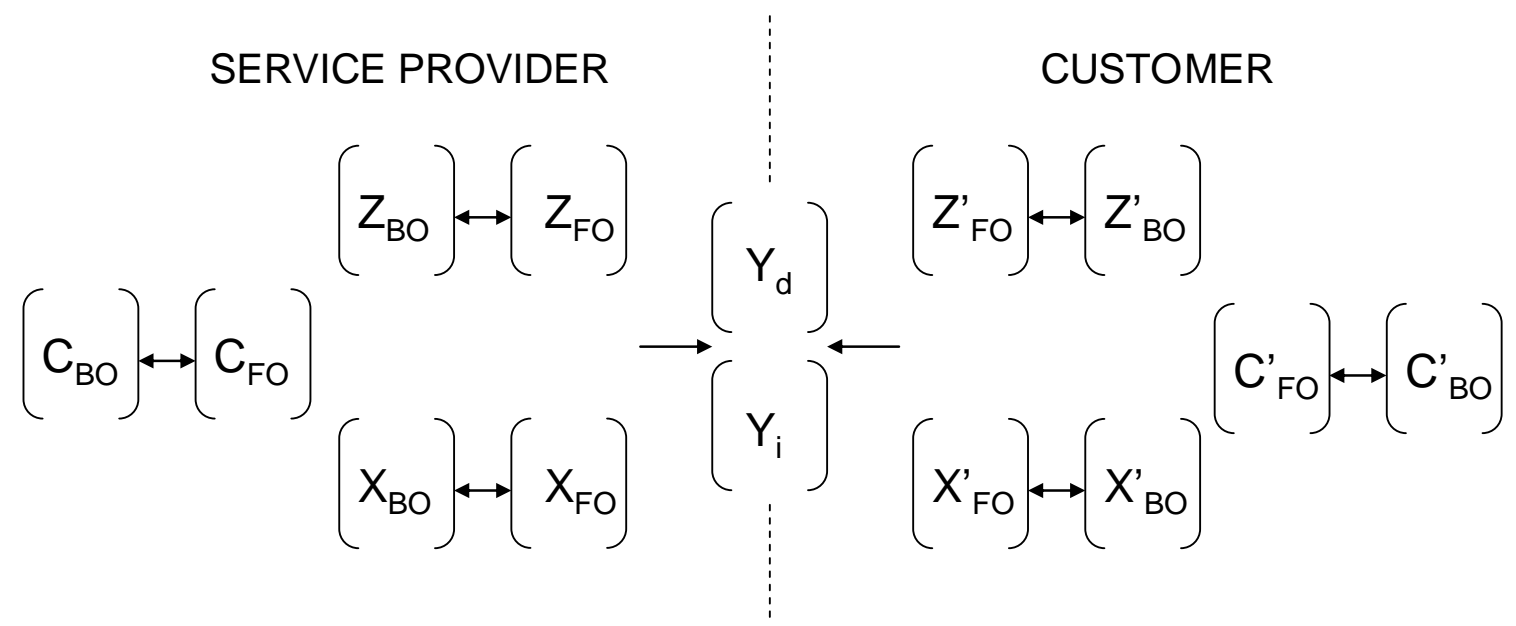


Table 1: Technical, process and competence characteristics of the service provider according to the 'front office - back office' division

\begin{tabular}{|c|c|c|c|}
\hline & technical characteristics $\mathrm{X}$ & process characteristics $\mathrm{Z}$ & competence characteristics $\mathrm{C}$ \\
\hline $\begin{array}{l}\text { 'back office' } \\
\text { BO }\end{array}$ & $\begin{array}{l}\text { - service concept } \\
\text { - prototype of the process } \\
\text { (blueprints, flowcharts) } \\
\text { - tangible technology } \\
\text { - non-technological models } \\
\text { and methods } \\
\text { - organisation } \\
\text { - physical environment } \\
\text { (e.g. ergonomics) }\end{array}$ & $\begin{array}{l}\text { - those parts of the service } \\
\text { design and production } \\
\text { which take place outside } \\
\text { the customer contact; } \\
\text { preparatory activities } \\
\text { regarding marketing }\end{array}$ & $\begin{array}{l}\text { - competences linked to } \\
\text { organisational learning and } \\
\text { organisational memory } \\
\text { - individual competences } \\
\text { mobilised in service } \\
\text { administration (e.g. CRM) }\end{array}$ \\
\hline $\begin{array}{l}\text { 'front office' } \\
\text { FO }\end{array}$ & $\begin{array}{l}\text { - concrete results (reports, } \\
\text { contracts, software etc.) } \\
\text { - tangible and non-tangible } \\
\text { technologies mobilised } \\
\text { - organisation mobilised } \\
\text { - physical environment } \\
\text { (if relevant) }\end{array}$ & $\begin{array}{l}\text { - the main part of service } \\
\text { marketing and those } \\
\text { parts of the service } \\
\text { design and production } \\
\text { which include customer } \\
\text { contact }\end{array}$ & $\begin{array}{l}\text { - individual competences } \\
\text { of the personnel mobilised } \\
\text { in the interaction with the } \\
\text { customer }\end{array}$ \\
\hline
\end{tabular}


Table 2: A characteristics-based analysis of the traditional architect's service and of the service based on the 'workplace design' framework

\section{Traditional architect's service}

\begin{tabular}{|l|l|}
\hline $\mathrm{X}_{\mathrm{BO}}$ & $\begin{array}{l}\text { no clear concept, tacit knowledge } \\
\text { central; methods focus on 'drawing' } \\
\text { and technology on architects' software }\end{array}$ \\
\hline $\mathrm{X}_{\mathrm{FO}}$ & $\begin{array}{l}\text { results presented as 'drawings', } \\
\text { supplemented with reports and } \\
\text { multimedia presentations }\end{array}$ \\
\hline
\end{tabular}

$\mathrm{Z}_{\mathrm{BO}} \quad$ the process follows the construction project (from general plans to details); cooperation with other planners

$\mathrm{Z}_{\mathrm{FO}}$ presenting the plans to the client in recurring meetings during the process

$\mathrm{C}_{\mathrm{BO}}$ architect's expertise is enough: design of functional and aesthetic spaces and awareness of laws and regulations

$\mathrm{C}_{\mathrm{FO}}$ ability to show one's expertise:

to reconcile the client's desires and the external limitations

\begin{tabular}{|c|c|c|}
\hline \multirow{3}{*}{$\begin{array}{l}\mathrm{Y}_{\mathrm{d}} \\
\text { the plan is in } \\
\text { line with the } \\
\text { client's order, } \\
\text { which often } \\
\text { favours brand } \\
\text { supporting and } \\
\text { economical } \\
\text { solutions }\end{array}$} & $\begin{array}{l}\text { specific technology is not needed; } \\
\text { some organisational resources are } \\
\text { mobilised (a project group/person) }\end{array}$ & $\mathrm{X}_{\mathrm{BO}}^{\prime}$ \\
\hline & $\begin{array}{l}\text { organisation is central also here; } \\
\text { the project group/person } \\
\text { cooperates with the architect }\end{array}$ & $\mathrm{X}_{\mathrm{FO}}^{\prime}$ \\
\hline & $\begin{array}{l}\text { the client seeks suitable planners, } \\
\text { organises tendering and selects an } \\
\text { architect (and other planners) }\end{array}$ & $Z_{\text {BO }}^{\prime}$ \\
\hline \multirow{3}{*}{$\begin{array}{l}\text { the } \mathrm{Y}_{\mathrm{i}} \\
\text { focuses on the } \\
\text { near future and } \\
\text { rarely includes } \\
\text { longer-term } \\
\text { analysis }\end{array}$} & $\begin{array}{l}\text { the client's order starts the } \\
\text { process; later the client accepts or } \\
\text { rejects plans or requires changes }\end{array}$ & $Z_{\mathrm{FO}}^{\prime}$ \\
\hline & $\begin{array}{l}\text { ability to analyse one's own space } \\
\text { needs and make decisions based } \\
\text { on the planner's suggestions }\end{array}$ & $\mathrm{C}_{\mathrm{BO}}^{\prime}$ \\
\hline & $\begin{array}{l}\text { ability to communicate one's own } \\
\text { space needs to the planner }\end{array}$ & $\mathrm{C}_{\mathrm{FO}}^{\prime}$ \\
\hline
\end{tabular}

Service based on the 'workplace design' framework

\begin{tabular}{|l|l|}
\hline $\mathrm{X}_{\mathrm{BO}}$ & $\begin{array}{l}\text { a clear service concept; new methods } \\
\text { for data analysis (e.g. behavioural } \\
\text { maps); internet technology central }\end{array}$ \\
\hline $\mathrm{X}_{\mathrm{FO}}$ & $\begin{array}{l}\text { on-site methods (e.g. observation); } \\
\text { results presented as reports and } \\
\text { illustrations }\end{array}$ \\
\hline
\end{tabular}

$\mathrm{Z}_{\mathrm{BO}}$ analysis of the client's space needs on the basis of data gathered on-site, linking the space needs to strategy

$\mathrm{Z}_{\mathrm{FO}}$ observing the behaviour of personnel in the client's premises, organising change workshops

\begin{tabular}{|l|l|}
\hline $\mathrm{C}_{\mathrm{BO}}$ & $\begin{array}{l}\text { understanding human behaviour and } \\
\text { strategic issues; multidisciplinarity; } \\
\text { proactive attitude }\end{array}$ \\
\hline $\mathrm{C}_{\mathrm{FO}}$ & $\begin{array}{l}\text { ability to illustrate how spaces } \\
\text { influence everyday work and to act as a } \\
\text { change agent }\end{array}$ \\
\hline
\end{tabular}

\section{$\mathrm{Y}_{\mathrm{d}}$}

the new office spaces support the strategy of the client; the process makes the personnel committed to changes

\section{$\mathrm{Y}_{\mathrm{i}}$} the solutions are planned for the future; they are flexible and changeable

\begin{tabular}{|l|l|}
$\begin{array}{l}\text { both organisational resources and } \\
\text { technology are needed (surveys } \\
\text { are carried out via internet) }\end{array}$ & $\mathrm{X}_{\text {BO }}$ \\
\hline $\begin{array}{l}\text { the client establishes a project } \\
\text { group; big companies even have } \\
\text { specific 'workplace departments' }\end{array}$ & $\mathrm{X}_{\mathrm{FO}}$ \\
\hline
\end{tabular}

in addition to earlier tasks, active $Z^{\prime}{ }_{\mathrm{BO}}$ in-house working is needed on the suggestions of the architect top management defines the aims $Z^{\prime}{ }_{F O}$ of the project; in later stages personnel is broadly involved

\begin{tabular}{|l|l|}
\hline strategic and future-oriented & $\mathrm{C}^{\prime}{ }_{\mathrm{BO}}$
\end{tabular} thinking, readiness to changes, devoting time for the project cooperative capabilities and active $\mathrm{C}^{\prime}{ }_{\mathrm{FO}}$ participation are highlighted due to the central role of workshops) 
Table 3: A characteristics-based analysis of the services mapping clients' insurance needs: a comparison between general service and age-specific 'fifty plus' service

\section{General needs mapping service}

\begin{tabular}{|c|c|c|c|c|}
\hline $\mathrm{X}_{\mathrm{B}}$ & $\begin{array}{l}\text { guidebooks and intranet material for } \\
\text { learning (these include e.g. interaction } \\
\text { models and question techniques) }\end{array}$ & \multirow{7}{*}{$\begin{array}{l}\text { answers to } \\
\text { the client's } \\
\text { problems } \\
\text { 'here and now' } \\
\text { (insurances, } \\
\text { deposits, loans } \\
\text { etc.) }\end{array}$} & $\begin{array}{l}\text { the client gets information about } \\
\text { the mapping service in internet, } \\
\text { where also self service is possible }\end{array}$ & $\mathrm{X}_{\text {BО }}^{\prime}$ \\
\hline $\mathrm{X}_{\mathrm{FO}}$ & $\begin{array}{l}\text { a tool for the calculation of the client's } \\
\text { social security; printed report and } \\
\text { product brochures for the client }\end{array}$ & & $\begin{array}{l}\text { the client can use internet for } \\
\text { making an appointment }\end{array}$ & $\mathrm{X}_{\mathrm{FO}}^{\prime}$ \\
\hline $\mathrm{Z}_{\mathrm{BO}}$ & $\begin{array}{l}\text { the official prepares the service session } \\
\text { and takes care of tasks resulting from it }\end{array}$ & & $\begin{array}{l}\text { the client gathers relevant } \\
\text { documents with him/her; solutions } \\
\text { are often made after the session }\end{array}$ & $Z^{\prime}{ }_{\text {BO }}$ \\
\hline $\mathrm{Z}_{\mathrm{FO}}$ & $\begin{array}{l}\text { the process may start on the official's } \\
\text { initiative; the actual interaction highly } \\
\text { dependent on the official's experience }\end{array}$ & & $\begin{array}{l}\text { the client consults the official } \\
\text { about his/her situation, and may } \\
\text { make some immediate decisions }\end{array}$ & $Z^{\prime}{ }_{\mathrm{FO}}$ \\
\hline & & & & \\
\hline $\mathrm{C}_{\mathrm{BO}}$ & $\begin{array}{l}\text { general knowledge about social } \\
\text { security, consumer economy and the } \\
\text { company's insurance products }\end{array}$ & & $\begin{array}{l}\text { initiative, planning and decision } \\
\text { making abilities in the issues of } \\
\text { personal or household economy }\end{array}$ & $\mathrm{C}^{\prime}{ }_{\mathrm{BO}}$ \\
\hline $\mathrm{C}_{\mathrm{FO}}$ & $\begin{array}{l}\text { general interaction skills; ability to } \\
\text { apply one's knowledge in the situation } \\
\text { of individual clients }\end{array}$ & & $\begin{array}{l}\text { ability to compare alternatives and } \\
\text { receive new information during } \\
\text { the service session }\end{array}$ & $\mathrm{C}_{\mathrm{FO}}^{\prime}$ \\
\hline
\end{tabular}

Needs mapping service for 'fifty plus' clients

\begin{tabular}{|c|c|c|c|c|}
\hline $\mathrm{X}_{\mathrm{BO}}$ & $\begin{array}{l}\text { a clear service concept; learning } \\
\text { material and check lists of 'fifty plus' } \\
\text { issues; specific organisational resources }\end{array}$ & \multirow{3}{*}{$\begin{array}{l}\text { 'here and } \\
\text { now' issues } \\
\text { are answered } \\
\text { as before } \\
\text { (separate from } \\
\text { the mapping) }\end{array}$} & $\begin{array}{l}\text { no change; internet is the only } \\
\text { technology needed by the client }\end{array}$ & $\mathrm{X}_{\text {BO }}^{\prime}$ \\
\hline $\mathrm{X}_{\mathrm{FO}}$ & $\begin{array}{l}\text { the calculation tool and report focus on } \\
\text { age-specific issues; a specific group } \\
\text { of advisors devoted to this service }\end{array}$ & & $\begin{array}{l}\text { no change; internet is the only } \\
\text { technology needed by the client }\end{array}$ & $\mathrm{X}_{\mathrm{FO}}^{\prime}$ \\
\hline $\mathrm{Z}_{\mathrm{BO}}$ & $\begin{array}{l}\text { steps of preparation and after-care } \\
\text { remain as before; training in 'fifty plus' } \\
\text { services is active }\end{array}$ & & $\begin{array}{l}\text { preparing and making solutions } \\
\text { take place as before }\end{array}$ & $Z_{\text {Во }}^{\prime}$ \\
\hline $\mathrm{Z}_{\mathrm{FO}}$ & $\begin{array}{l}\text { steps of the process do not change, but } \\
\text { the service quality is more uniform and } \\
\text { discussion more focused }\end{array}$ & $\begin{array}{r}\mathrm{Y}_{\mathrm{i}} \\
\text { detailed }\end{array}$ & $\begin{array}{l}\text { consultation takes place as before, } \\
\text { but the client gets more detailed } \\
\text { and comprehensive information }\end{array}$ & $Z_{\text {FO }}^{\prime}$ \\
\hline $\mathrm{C}_{\mathrm{BO}}$ & $\begin{array}{l}\text { focus on specific know-how regarding } \\
\text { the development of senior services and } \\
\text { the treatment of age-specific issues }\end{array}$ & $\begin{array}{l}\text { issues linked } \\
\text { to senior years } \\
\text { supports the }\end{array}$ & $\begin{array}{l}\text { readiness to take an active stance } \\
\text { to the planning of one's future } \\
\text { also at an advanced age }\end{array}$ & $\mathrm{C}^{\prime}{ }_{\text {во }}$ \\
\hline $\mathrm{C}_{\mathrm{FO}}$ & $\begin{array}{l}\text { avoiding stereotypes and showing } \\
\text { factual knowledge about the issues } \\
\text { relevant for 'fifty plus' clients }\end{array}$ & $\begin{array}{l}\text { client in his/ } \\
\text { her solutions }\end{array}$ & $\begin{array}{l}\text { readiness to receive information } \\
\text { and tackle issues that one has not } \\
\text { thought about before }\end{array}$ & $\mathrm{C}_{\mathrm{FO}}^{\prime}$ \\
\hline
\end{tabular}

